\title{
KEBANGKRUTAN BANK PASCA KRISIS EKONOMI GLOBAL DI ASEAN
}

\author{
M Riski Rumalutur ${ }^{1}$, Suhartono ${ }^{2}$, Abdul Mongid ${ }^{3}$ \\ ${ }^{1,2,3)}$ STIE Perbanas Surabaya
}

\begin{abstract}
This study aims to determine the factors that can determine bank bankruptcy after the global economic crisis in ASEAN. The independent variables used in this study are Inflation, Gross Domestic Product (GDP), Equity To Total Assets (ETA), and SIZE. The analytical technique used is logistic regression analysis. The data is processed using STATA, and this study uses a population of ASEAN banks with a sample of 1300 banks. This study indicates that inflation has an insignificant positive effect on bank bankruptcy. GDP has a negligible negative impact on bank bankruptcy, ETA has a significant positive impact on bank bankruptcy, and size has a significant negative effect on bank bankruptcy.
\end{abstract}

Keywords $\quad$ : Bankruptcy; ETA; GDP; Inflation; SIZE

Correspondence to : riskirumalutur00@gmail.com

\begin{abstract}
ABSTRAK
Penelitian ini bertujuan untuk mengetahui faktor-faktor yang dapat menentukan kebangkrutan bank pasca krisis ekonomi globa di ASEAN. Variabel independen yang digunakan dalam penelitian ini adalah Inflasi, Gross Domestic Product (GDP), Equity To Total Asset (ETA), dan SIZE. Teknik analisis yang digunakan yaitu analisis regresi logistic, data diolah menggunakan STATA, penelitian ini menggunakan populasi bank ASEAN dengan sampel bank sebanyak 1300 bank. Hasil penelitian ini menunjukan bahwa Inflasi berpengaruh positif tidak signifikan terhadap kebangkrutan bank, GDP berpengaruh negative tidak signifikan terhadap kebangkrutan bank, ETA berpengaruh positif signifikan terhadap kebangrutan bank, dan size berpengaruh negative signifikan terhadap kebangkrutan bank.
\end{abstract}

Kata Kunci $\quad$ : ETA; GDP; Inflasi; Kebangkrutan; SIZE

Riwayat Artikel:

Received : 23 Maret 2021

Revised: 04 Mei 2021

Accepted : 29 Juni 2021

\section{PENDAHULUAN}

Sektor perbankan adalah sektor perekonomian terpenting dalam suatu negara. Perbankan mempunya peran sebagai institusi intermediasi, jika fungsi perbankan sebagai intermediasi berjalan dengan baik maka akan membentuk stabilitas sistem keuangan yang baik, dengan demikian akan menumbuhkan pereonomian sesuai dengan yang ditargetkan sebelumnya. Peranan yang paling utama suatu perbankan di Indonesia sesuai dengan Undang-undang Republik Indonesia No. 7 tahun 1992 mengenai perbankan. Yang mana sudah mengalami amandemen menjadi UU No.10 Tahun 1998 merupakan menghimpun dana dari penduduk berbentuk simpanan serta menyalurakan pada penduduk dalam bentuk kredit. Pabrik perbankan bertumbuh dengan cepat pada tahun 1988-1996, jumlah bank semakin mengalami kenaikan serta mengeluarkan bermacam macam produk perbankan yang inovatif. Pada faktanya banyak bank yang kurang berwaspada dalam 
menghimpun dana penduduk serta menyalurkan dalam bentuk kredit, akibatnya menyimpang dari aturan-aturan yang legal dalam perusahaan perbankan.

Pada saat Indonesia mengalami krisis keuangan tahun 1997-1998 telah mengakibatkan penurunan kondisi perbankan Indonesia. Krisis ini telah menurunkan tingkat kepercayaan masyarakat terhadap bank, sehingga pemerintah terpaksa mengambil berbagai langkah kebijakan untuk menyelamatkan industri perbankan dan mengembalikan kepercayaan masyarakat. Dan krisis perbankan terulang kembali pada tahun 1997-1998 juga pada tahun 2008 adalah suasana ketidak pastiaan karena suku bunga mahal, ketatnya likuiditas, pinjaman macet serta penyusutan angka mata duit rupiah pada dollar. kegentingan itu berasal dari subprime mortage atau disebut pula housing bubble yang memiliki kekeliruan paradigma jika" Aset perumahaan bakal selalu naik, housing never lose value, safe investment". Selaku sampel institusi yang ikut mempengaruhi krisis di Indonesia yaitu Lehman Brothers dan Washington Mutual (Trader.com).

Imbas langsung kritis finansial ini untuk Indonesia yaitu kesusahan sebagian industri di Indonesia yang mendanakan di institusiinstitusi finansial Amerika Serikat. Perusahaan finansial atau non bank yang membagikan dana pada sumber pemasukan opsi lain, melalui pembelian saham ataupun surat pinjaman pada instrumen finansial asing, semacam Citigroup, UBS, Merril Lynch, Morgan Stanley, Lehman Brothers, Fannie Mae, Freddie Mac, American International Group( AIG) serta yang ada. Sebaliknya imbas tidak langsung dari krisis merupakan turunnya likuiditas, melonjaknya tingkatan suku bunga, turunnya harga barang, melemahnya angka ubah rupiah, serta melemahnya perkembangan sumber dana. Begitu pula, menyusutnya tingkatan keyakinan pelanggan, penanam modal, serta pasar kepada bermacam institusi finansial yang menimbulkan melemahnya pasar modal.

Dalam penelitian (Sudarsono 2009) menerangkan Krisis finansial pula mengurangi simpanan likuditas bagian finansial sebab bangkrutnya sebagian institusi finansial internasional khususnya bank- bank pemodalan yang mempengaruhi pada gerakan kas perusahaan- perusahaan di Indonesia.
Kondisi ini hendak menimbulkan menaiknya tingkatan suku bunga serta turunnya pendanaan ke pasar modal serta perbankan garis besar. Pada tahun 2008 situasi Bank Century jadi terus menjadi memburuk dampak lemahnya pengawasan dalam serta lemahnya penerapan sistem melaksanakan yang bagus akibatnya mengakibatkan terbentuknya fraud serta kerugian yang lumayan besar (Kusmayadi 2012). Penguasa mengakhiri membagikan pertolongan likuiditas dengan 2 estimasi. Pertama, untuk mencegah kebutuhan pelanggan serta penanam modal. Kedua, untuk melindungi keyakinan.

Imbas negatif dari krisis internasional yang dialami oleh Indonesia antara lain yaitu meningkatnya nila tukar rupiah, tingginya nilai inflasi serta menyusutnya perkembangan Produk Dalam negeri Bruto( PDB). Saat sebelum Lehman Brothers memublikasikan kebangkrutannya nilai tukar rupiah sedang terletak pada tingkat Rp 9.000 per dolar AS. Akan tetapi seperti itu Lehman Borthers melaporkan ambruk, rupiah mulai fluktuasi sampai mendobrak nilai Rp 12. 650 per dolar AS pada 24 November 2008. Pelemahan rupiah rentang waktu September ke Desember 2008 berdampak pada bisnis valas perbankan (Humas Bank Indonesia,2010).

Kegiatan usaha perbankan dapat memicu adanya risiko yang mengakibatkan menurunnya kinerja bank, seperti menurunnya kepercayaan masyarakat serta kesulitankesulitan lainnya. Kesulitan yang dihadapi perbankan tercermin dari indikator kinerja yang dapat menimbulkan kesulitan jangka panjang apabila kesulitan likuiditas jangka pendek tidak segera diatasi. Bank dapat dikatakan gagal saat bank tidak bisa menjalankan kegiatan oprasional dan mengalami kerugian selama beberapa tahun. Maka dari itu memerlukan pencegahan dini (early warning) untuk mencegah terjadinya kegagalan.

Penelitian ini mempunyai tujuan agar diketahui aspek-aspek untuk menentukan kebangkrutan bank. Faktor yang digunakan dalam kebangkrutan bank antara lain: Inflasi, Gross Domestic Product (GDP), Equity to Total Assets Ratio (ETA), dan SIZE. Dalam penelitian ini kebangrutan bank diukur menggunakan Return On Average Assets (ROAA). (Kasus et al. 2014) Model Traffer 
menetapkan rasio profitabilitas sebagai diskriminan paling penting bagi perusahaan yang sehat dan bangkrut. Menurut (Khadapi 2017) Faktor internal maupun eksternal yang menyebabkan kondisi kesulitan keuangan. Faktor internal diantaranya: perusahaan mengalami rugi selama beberapa periode dari kegiatan operasional, besarnya jumlah hutang serta kesulitan arus kas. Faktor eksternal meliputi: suku bunga pinjaman menigkat, mengakibatkan beban bunga yang ditanggung perusahaan juga bertambah naik, lain dari itu ada pula meningkatnya biaya-biaya tenaga kerja yang menyebabkan besarnya biaya operasional suatu perusahaan juga mengalami kenaikan.

Inflasi adalah kenaikan harga-harga secara umum dan berlangsung secara terusmenerus dalam rentan waktu tertentu (asfia murni, 2016:218). Untuk mengukur tingkat inflasi, indikator yang dapat digunakan yaitu indeks harga konsumen (IHK).

$G D P$ atau PDB merupakan indikator pertumbuhan ekonomi dan indikator penting efisiensi kegiatan ekonomi, yang merupakan akibat langsung dari kegiatan ekonomi penyediaan barang dan jasa, termasuk industri perbankan. Menurut (Firdaus 2016) komponen PDB adalah konsumsi rumah tangga, pengeluaran investasi, pengeluaran publik dan selisih antara ekspor dan impor. PDB memberikan perkiraan terbaik untuk mengukur tingkat produksi. Menurut (MN and Permatasari 2017) Semakin tinggi nilai PDB, semakin menguntungkan perekonomian di sektor perbankan, tetapi PDB yang lebih rendah mempengaruhi kesehatan bank.

Rasio modal/total aset adalah metrik keuangan yang digunakan untuk mengukur keterikatan atau motivasi pemilik terhadap kelangsungan operasi bank yang bersangkutan. Rasio ini menunjukkan jumlah modal yang digunakan untuk berinvestasi dalam total aset perusahaan. Semakin tinggi prosesnya, semakin baik.

Size mengacu pada ukuran bank seperti yang tampak dalam total aset perusahaan. Bank-bank besar memiliki volume transaksi yang banyak, dan semakin tinggi volumenya, semakin tinggi pula keuntungan bank tersebut. Bank dengan total aset tinggi biasanya tidak bangkrut. Bank yang besar dapat memberikan kepercayaan lebih kepada investor dan nasabah terhadap dana yang telah mereka investasikan di bank tersebut. Penelitian (Hadyu Hasanatina, Mawardi, and Manajemen 2016) menyatakan semakin besar maka akan meningkatkan kestabilan bank dalam menghadapi keadaan ekonomi.

\section{METODE PENELITIAN}

\section{Kerangka pemikiran}

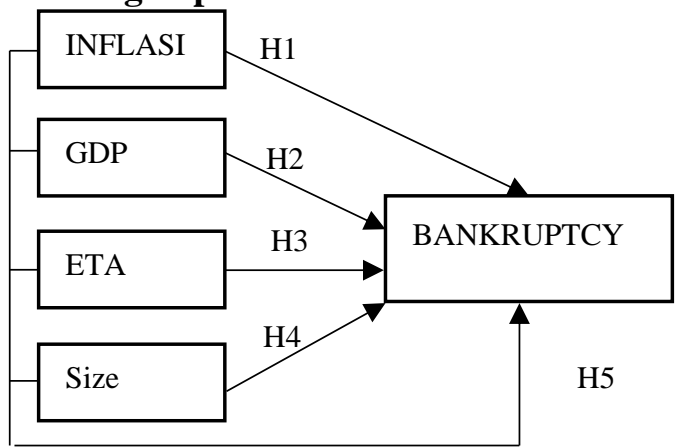

Gambar. 1

Kerangka Pemikiran

Dimana :

$$
\begin{array}{ll}
\mathrm{Y} & =\text { Bankruptcy } \\
\mathrm{X} 1 & =\text { Inflasi } \\
\mathrm{X} 2 & =\text { Gross Domestic Product }(G D P) \\
\mathrm{X} 3 & =\text { Equity to total asset }(\text { ETA }) \\
\mathrm{X} 4 & =\text { SIZE }
\end{array}
$$

\section{Hipotesa Penelitian}

Rancangan diatas melahirkan pemikiran dan dapat disusun hipotesisa Penelitian sebagai berikut :

H1 : INFLASI dapat menjadi penentu kebangkrutan bank.

$\mathrm{H} 2$ : GDP dapat menjadi penentu kebangkrutan bank.

H3 : ETA dapat menjadi penentu kebangkrutan bank.

H4 : SIZE dapat menjadi penentu kebangkrutan bank.

H5 : Inflation, Gross Domestic Produck (GDP), Equity to Total Assets Ratio (ETA), dan Size secara simultan dapat menjadi penentu kebangkrutan bank.

\section{Pengelompokan sampel dan Teknik Analisis Data}

Populasi dalam Penelitian ini yaitu seluruh bank di asean. Bank yang tertera di bankscope database tahun 2014-2018 adalah sampelnya. purposive sampling adalah metode 
yang dipakai dalam Penelitian ini. Pada penelitian ini menggunakan teknik analisis deskriptif dan regresi logistik. Data ini akan diolah menggunakan STATA

\section{Definisi Operasional Variabel Kebangkrutan}

Kebangkrutan bank adalah kondisi diamana bank tidak dapat memenuhi kewajiban dan gagal dalam menjalankan oprasional bank. Kebangkrutan bank dapat diprosikan dengan rasio ROAA $<=0$. , Rumus untuk mengukur ROAA sebagai berikut.

$$
R O A A=\frac{\text { laba bersih setelah pajak }}{\text { rata }- \text { rata total aset }}
$$

\section{Inflasi}

Inflasi merupakan suatu kondisi harga yang fluktuatif dari waktu kewaktu. Tetapi kenaikan harga tidak selalu dalam presentase yang sama. Kenaikan harga terhadap satu atau dua produk belum dapat dikatakan inflasi. Rumus yang digunakan untuk menghitung inflasi yaitu.

$$
\text { In }=\frac{I H K n-I H K n-1}{I H K n-1} \times 100
$$

Gross Domestic Product (GDP)

GDP adalah indikator untuk mengukur perekonomian suatu negara dengan total pendapatan semua orang dalam perekonomian dan total pembelanjaan negara. Rumus yang diginakan untuk menghitung GDP yaitu.

$$
G D P=W+r+i+p
$$

\section{Equity to Total Asset ( ETA )}

Perbandingan antara total modal sendiri dengan total asset sebuah bank. Indikator finansial ini dipakai untuk mengukur motivasi dari pemilik atas usaha yang dijalankan. Rumus yang digunakan untuk yaitu.

Size

$$
\text { ETA }=\frac{\text { Total Ekuitas }}{\text { Total Aset }}
$$

Size ditunjukan dari besaran total aset yang ada pada bank. Jika bank yang mempunyai ukuran yang besar maka volume usaha bank tersebut juga besar. Rumus yang dipakai untuk mengukur Size yaitu.

$$
\text { Size }=\operatorname{Ln}(\text { Total Aset })
$$

\section{HASIL PENELITIAN}

Subyek penelitian ini menggunakan perbankan yang terdaftar di bankscope dan terdiri dari 9 negara ASEAN pada periode 2014-2108. Jumlah data bank yang dipakai dalam Penelitian ini sebanyak 1300 bank.

\section{Analisa Data Deskriptif}

Metode deskriptif merupakan teknik analisis yang mendeskripsikan ataupun menganalisa sesuatu hasil penelitian namun tidak dipakai agar diketahui hipotesa lebih luas (Sugiyono, 2005: 21). Pada prosedur di pakai selaku perlengkapan untuk memaparkan faktor-faktor dalam Penelitian ini. Faktorfaktor yang akan dipaparkan dengan tata cara ini yaitu : Inflation, GDP, ETA, dan Size

TABEL 1. Analisis Deskriptif

\begin{tabular}{ccccc}
\hline \multicolumn{5}{c}{ Tidak Bangkrut } \\
\hline & Inflasi & GDP & ETA & Size \\
\hline Mean & 4.638029 & 5.184413 & 16.30744 & 14.590 .161 \\
\hline Min & -0.849 & -2.508 & -11.77 & 10.216 \\
\hline Max & 23.116 & 14.526 & 99.85 & 334.000 .000 \\
\hline Std. & 3.30529 & 2.473602 & 14.14849 & 39.567 .214 \\
Dev & \multicolumn{5}{c}{ Bangkrut } \\
\hline \multicolumn{5}{c}{ GTA } \\
\hline Mean & 5.154745 & 4.894043 & 31.34247 & 9.963 .527 \\
\hline Min & -0.849 & -0.708 & -3.28 & 16.192 \\
\hline Max & 26.8 & 10.55 & 97.73 & 314.000 .000 \\
\hline Std. & 5.429098 & 2.650329 & 28.78344 & 4.5019 .273 \\
Dev & \multicolumn{5}{c}{} \\
\hline
\end{tabular}

\section{Inflasi}

Pada tabel 1 menunjukan average value inflasinya bank yang bangkrut sebesar 5,154 , sedangkan pada bank yang tidak mengalami kebangkrutan sebesar 4,638. Ini menunjukan bahwa bank yang mengalami kebangkrutan memiliki average tinggi bila berbanding dengan bank yang tidak mengalami kebangkrutan. Pada tabel 1 dapat diketahui Inflasi tertinggi pada bank yang mengalami kebangkrutan sebesar 26,8 yang di alami oleh bank Myanma Economic Bank (2008), sedangkan inflasi terendah pada bank yang mengalami kebangkrutan sebesar $-0,849$ yang di alami oleh bank Mizuho Corporate Bank, Ltd.(2009) dan CIMB Thai Bank Public Company Limited (2009).

Pada tabel 1 dapat diketahui inflasi tertinggi pada bank yang tidak mengalami 
kebangkrutan sebesar 23,116 yang dialami oleh bank Saigon Commercial BankSaigonbank, VID Public Bank, dan VinaSiam Bank (2008), sedangkan inflasi terendah pada yang tidak mengalami kebangkrutan sebesar 0,849 yang dialami oleh bank Government Housing Bank (2009). Dapat disimpulkan inflasi yang dialamai oleh bank-bank yang mengalami kebangkrutan lebih tinggi dibandingkan dengan bank yang tidak mengalami kebangkrutan.

\section{Gross Domestic Product (GDP)}

Pada tabel 1 dapat diketahui nilai ratarata (mean) Gross domestic product (GDP) pada bank yang mengalami kebangkrutan sebesar 4,89 sedangkan pada bank yang tidak mengalami kebangkrutan sebesar 5,18. Pada situasi tersebut bisa dikatakan jika bank tidak mendapatkan kebangkrutan dikarenakan mempunyai mean atau rata-rata dengan bank mengalami kondisi kebangkrutan. Ini menandakan bahwa pertumbuhan perekonomian pada bank yang tidak mengalami kebangkrutan lebih baik dibandingkan dengan bank yang mengalami kebangkrutan. Pertumbuhan ekonomi dapat mempengaruhi atau berdampak pada sektor perbankan, meningkatnya GDP menunjukkan bahwa kondisi ekonomi suatu Negara dalam keadaan positif. Tentu saja uasha-usaha dalam negara semakin baik termasuk sektor perbankan.

Pada tabel 1 dapat diketahui Gross demostic Product tertinggi pada bank yang mengalami kebangkrutan sebesar 10,55 yang dialami oleh bank Myanma Economic Bank (2009), sedangkan GDP terendah pada bank yang mengalami kebangkrutan sebesar $-0,708$ yang dialami oleh bank CIMB Thai Bank Public Company Limited (2009). Pada tabel 1 menunjukan GDP tertinggi pada bank yang mengalami kondisi kebangkrutan sebesar 14,52 yang dialami oleh bank Maybank Kim Eng Holdings Limited (2010), sedangkan GDP terendah pada bank yang yang tidak mengalami kondisi kebangkrutan sebesar 2,508 yang dialami oleh bank Bandar Seri Begawan (2014).

\section{Equity To Total Asset (ETA)}

Pada tabel 1 menunjukan nilai ratarata equity to total asset (ETA) pada bank yang mengalami kebangkrutan sebesar 31,34 sedangkan pada bank yang tidak mengalami kebangkrutan sebesar 16,30. Dilihat dari kedua kondisi teresbut dapat diketahui peranan atau motivasi dari pemilik kelangsungan usaha pada bank bersangkutan nilai rata-rata pada bank yang mengalami kebangkrutan lebih besar dibandingkan bank yang tidak mengalami kebangkrutan.

Pada tabel 1 nilai menunjukan rasio ETA tertinggi pada bank yang mengalami kebangkrutan sebesar 97,73 yang dialami oleh bank BNP Paribas Trust Services Singapore Limited (2008), sedangkan rasio tertinggi pada bank yang tidak mengalami kebangkrutan sebesar 99,85 yang dialami oleh bank ING Thai Asian USD Bond Fund (2008). Pada table 1 menunjukan rasio ETA terendah pada bank yang mengalami kebangkrutan sebesar 3,28 yang dialami oleh PT Bank Pundi Indonesia (2009), sedangkan rasio ETA terendah pada bank yang tidak mengalami kondisi kebangkrutan sebesar $-11,77$ yang dialami oleh Joint Development Bank Limited (The) (2008).

\section{Size}

Pada tabel 1 menunjukan nilai rata-rata (mean) size pada bank yang mengalami kebangkrutan sebesar 9.963.527, sedangakan nilai rata-rata pada bank yang tidak mengalami kebangkrutan sebesar 14.590.161. dilihat dari kedua kondisi tersebut asset pada bank yang tidak mengalami kebangkrutan lebih besar dibandingkan pada bank yang mengalami kebangkrutan, asset yang besar dapat meningkatkan kepercayaan investor atau nasabah untuk melakukan investasi atau pembiayaan pada bank.

Pada table 1 menunjukan bahwa size tertinggi pada bank yang mengalami kebangkrutan sebesar 314.000.000 yang dimiliki oleh Myanma Economic Bank (2009), sedangkan pada bank yang tidak mengalami kebangkrutan sebesar 334.000 .000 yang dimiliki oleh DBS Bank Ltd (2014). Pada tabel 1 menunjukan bahwa size terendah pada bank yang mengalami kebangkrutan sebesar 16.192 yang dimiliki oleh Indochina Bank (2008), sedangkan pada bank yang tidak mengalami kondisi kebangkrutan sebesar 10,216 yang dimiliki oleh BNP Paribas Trust Services Singapore Limited (2010). 


\section{Analisa Regresi Logistik}

Analisa atau pengujian ini dilakukan untuk dapat mengetahui apakah hipotesis Penelitian ini diterima atau di tolak. Jika nilai signifikan kurang dari 0,05 maka Ho diterima dan sebaliknya.

TABEL 2. Regresi Logistik

\begin{tabular}{|c|c|c|c|c|c|c|}
\hline Fail & Coef & $\begin{array}{l}\text { Std. } \\
\text { Err }\end{array}$ & Z & $\mathrm{P}>|\mathrm{z}|$ & $\begin{array}{l}{[95 \%} \\
\text { Inter }\end{array}$ & $\begin{array}{l}\text { onf. } \\
\text { ] }\end{array}$ \\
\hline Inflasi & 0.017 & $\begin{array}{l}0.02 \\
9\end{array}$ & $\begin{array}{l}0.6 \\
0\end{array}$ & $\begin{array}{l}0.54 \\
6\end{array}$ & $\begin{array}{l}0.03 \\
9\end{array}$ & $\begin{array}{l}0.07 \\
5\end{array}$ \\
\hline$G D P$ & $-\overline{0.055}$ & $\begin{array}{l}0.50 \\
6\end{array}$ & $\begin{array}{l}- \\
1.1 \\
0\end{array}$ & $\begin{array}{l}0.27 \\
3\end{array}$ & $\begin{array}{l}- \\
0.15 \\
4\end{array}$ & $\begin{array}{l}0.04 \\
3\end{array}$ \\
\hline ETA & 0.012 & $\begin{array}{l}0.00 \\
6 \\
\end{array}$ & $\begin{array}{l}1.9 \\
8 \\
\end{array}$ & $\begin{array}{l}0.04 \\
7 \\
\end{array}$ & $\begin{array}{l}0.00 \\
0 \\
\end{array}$ & $\begin{array}{l}0.02 \\
4 \\
\end{array}$ \\
\hline SIZE & $-\overline{0}$ & $\begin{array}{l}0.08 \\
1\end{array}$ & $\begin{array}{l}- \\
5.4 \\
7\end{array}$ & $\begin{array}{l}0.00 \\
0\end{array}$ & $\begin{array}{l}- \\
0.61 \\
0\end{array}$ & $\begin{array}{l}- \\
0.28 \\
4\end{array}$ \\
\hline$\overline{\mathrm{S}}_{\mathrm{CON}}^{\mathrm{CON}}$ & 3.290 & $\begin{array}{l}1.21 \\
3 \\
\end{array}$ & $\begin{array}{l}2.7 \\
1 \\
\end{array}$ & $\begin{array}{l}0.00 \\
7 \\
\end{array}$ & $\begin{array}{l}0.91 \\
2 \\
\end{array}$ & $\begin{array}{l}5.66 \\
7 \\
\end{array}$ \\
\hline
\end{tabular}

Berdasarkan table 2 hasil analisa regresi logistik pada tabel di atas dapat di jelaskan sebagai berikut:

Inflasi memiliki tingakat signifikan sebesar $0,546>0,05$.

$G D P$ memiliki nilai signifikan sebesar 0,273 > 0,05

ETA memiliki nilai signifikan sebesar 0,047 < 0,05

Size memiliki nilai signifikan sebesar $0,000<$ 0,05

Dengan demikian model Penelitian yang dapat disimpukan dalam persamaan sebagai berikut :

$\mathrm{Ln} \mathrm{BB} /(1-\mathrm{BB})=3,290+0,017$ inflasit $-1+(-$ $0,055)$ GDPt-1 + 0,012ETAt-1 + $(0,442)$ SIZEt-1 + e

\section{Uji Keseluruhan Model (Overal Model Fit)}

Hipotesis untuk mengetahui model fit:

$\mathrm{H}_{\mathrm{O}} \quad$ : model yang dihipotesiskan fit dengan data

$\mathrm{H}_{\mathrm{A}} \quad$ : model yang dihipotesiskan tidak fit dengan data

TABEL 3. Nilai -2 Log Likelihood

\begin{tabular}{cc}
\hline-2 Log Likelihood & Nilai \\
\hline Block 0 & 297.802 \\
\hline Block 1 & 261.278 \\
\hline
\end{tabular}

Nilai -2 Log Likelihood pada tabel 2 block 0 sebesar 297.802 sedangkan nilai -2 Log Likelihood pada block 1 sebesar 261.278. Nilai -2 Log Likelihood pada block 0 mengalami penurunan pada block 1. Dengan ini dapat disimpulkan bawha Ho diterima yaitu model yang dihipotesiskan fit dengan data yang dimana variable independen dapat menentukan kondisi kebangkrutan.

\section{Uji kelayakan model regresi}

Uji ini untuk mengukur seberapa besar kemampuan variable dependen dapat dijelaskan oleh variable independen.

TABEL 4. Nilai Pseudo $\mathbf{R}^{2}$

\begin{tabular}{c}
\hline Pseudo R $^{2}$ \\
\hline 0,1226 \\
\hline
\end{tabular}

Pada tabel 4 diatas dapat diketahui bahwa nilai Pseudo R2 sebesar 0,1226 yang artinya variable dependen dapat dijelaskan oleh variable independen sebesar $12,26 \%$.

\section{Hosmer And Lemeshow's Goodness Of Fit} Test

Untuk mengetahui data empiris sesuai dengan model.

TABEL 5. Hosmer And Lemeshow's Goodness Of Fit Test

\begin{tabular}{cccc}
\hline Total & Groups & Chi-Square & Sig \\
\hline 1300 & 5 & 2,67 & 0,445 \\
\hline
\end{tabular}

Pada tabel 5 dapat diketahui bahwa nilai Hosmer And Lemeshow's Goodness Of Fit sebesar 2,67 dan probabilitas signifikan sebesar 0,445 lebih besar dari 0,05. Dapat disimpulkan bahwa H0 diterima, artinya tidak ada perbedaan antara data empiris dengan model regresi dan dapat dikatakan model regresi ini fit.

\section{Matriks klasifikasi}

Tabel ini digunakan untuk menghitung estimasi atau prediksi yang benar (correct) dan salah (incorrect). 
TABEL 6. Matriks Klasifikasi

\begin{tabular}{lccc}
\hline \multirow{2}{*}{ Observasi } & \multirow{2}{*}{ Jumlah } & \multicolumn{2}{c}{ Prediksi } \\
\cline { 3 - 4 } & Bank & Tidak Bangkrut & Bangkrut \\
\hline Tidak & 1221 & 1219 & 78 \\
Bangkrut & & 2 & 1 \\
\hline Bangkrut & 79 & 1221 & 79 \\
\hline Total Bank & 1300 & $99,84 \%$ & $1,27 \%$ \\
\hline Persentase & \multicolumn{3}{c}{$93,85 \%$} \\
\hline $\begin{array}{l}\text { Persentase } \\
\text { Keseluruhan }\end{array}$ & \multicolumn{3}{c}{} \\
\hline
\end{tabular}

Pada tabel 6 dapat diketahui jumlah bank yang diprediksi tidak mengalami kebangkrutan sebanyak 1219 bank, sedangkan hasil observasi jumlah bank yang tidak mengalami kebangkrutan sebanyak 1221, sehingga presentase ketepatan prediksi sebesar $99,84 \%$ yang diperoleh dari $(1219 / 1221) \mathrm{x}$ $100 \%$.

Pada tabel 6 dapat diketahui jumlah bank yang diprediksi bangkrut sebanyak 1 bank, sedangkan hasil observasi pada bank yang mengalami kebangkrutan sebanyak 79 bank, sehingga presentase ketepatan prediksi sebesar $1,27 \%$ yang diperoleh dari (1/79) $\mathrm{x}$ 100\%. Dapat disimpulkan secara keseluruhan model ini memiliki ketepatan untuk memprediksi sebesar 93,85\%.

\section{Uji Hipotesis}

\section{H1 : Inflasi Tidak Dapat Memprediksi Kebangkrutan Bank.}

Pada tabel 2 nilai koefisien inflasi sebesar 0,017 ini menunjukan semakin tinggi tingkat inflasi maka potensi bank mengalami kebangkrutan akan semakin tinggi. Variable inflasi memiliki tingkat signifikansi sebesar 0,546 lebih besar dari tinggkat alpha yaitu 0,05 . Ini membuktikan bahwa inflasi memiliki pengaruh positif tidak signifikan. karena nilai signifikasi inflasi $0,546>0,05$. Dapat disimpulkan bahwa inflasi tidak dapat memprediksi kebangkrutan bank.

\section{H2 : GDP Dapat Memprediksi} Kebangkrutan Bank.

Pada tabel 2 nilai koefisien $G D P$ sebesar -0,055 ini menunjuka bahwa semakin tinggi GDP makan potensi bank mengalami kebangkrutan akan semakin kecil. Variable GDP memiliki tingkat signifikasi sebesar 0,273 lebih besar dari tinggkat alpha yaitu 0,05 . Ini menunjukan bahwa GDP secara positif bersignifikasi GDP 0,273>0,05. Dapat disimpulkan bahwa GDP tidak dapat memprediksi kebangkrutan bank.

\section{H3 : ETA Dapat Memprediksi Kebangkrutan Bank. \\ Pada tabel 4.3 nilai koefisien ETA} sebesar 0.012 ini menunjukan semakin tinggi ETA maka potensi bank mengalami kebangkrutan akan semakin tinggi. Variable ETA memiliki tingkat signifikansi sebesar 0,047 lebih kecil dari tinggkat alpha yaitu 0,05. Ini menunjukan bahwa ETA memiliki pengaruh positif signifikan. karena nilai signifikasi ETA $0,047<0,05$. Dapat disimpulkan bahwa ETA dapat memprediksi kebangkrutan bank.

\section{H4 : SIZE Dapat Memprediksi Kebangkrutan Bank.}

Pada tabel 4.3 nilai koefisien size sebesar -0,442 ini menunjuka bahwa semakin tinggi size makan potensi bank mengalami kebangkrutan akan semakin kecil. Variable size memiliki tingkat signifikansi sebesar 0,000 lebih kecil dari tinggkat alpha yaitu 0,05 . Ini menunjukan bahwa size memiliki pengaruh positif signifikan. karena nilai signifikasi SIZE $0,000<0,05$. Dapat disimpulkan bahwa SIZE dapat memprediksi kebangkrutan bank.

H5 : Inflasi, GDP, ETA, Dan Size Secara Simultan Dapat Memprediksi Kebangkrutan Bank.

Variabel inflasi, GDP, ETA, dan size secara simultan dapat memprediksi kebangkrutan bank, karena nilai LR chi2 sebsar 73,05 lebih besar dari tinggkat alpha yaitu 0,05 .

\section{PEMBAHASAN}

Berdasarkan hasil pengujian diatas, dapat disimpulkan bahwa variabel independen yaitu Inflasi, GDP, ETA, dan SIZE secara simultan dapat memprediksi kebangkrutan bank. Menurut hasil uji coba terpisah, faktor variabel beba yang dapat memprediksi kebangkrutan bank adalah ETA dan SIZE, sedangkan variabel inflasi dan GDP secara parsial tidak dapat memprediksi kebangkrutan bank. 


\section{Inflasi Dapat Menjadi Penentu Kebangkrutan Bank \\ Inflasi merupakan kenaikan harga} barang dan jasa dalam suatu perekoomian secara terus menerus dari waktu ke waktu. Inflasi ialah goncangan dari harga nominal, yang tampaknya akan bersinggungan dengan tingkat kaum bunga nominal dan bisa menjadi salah satu faktor yang memperkirakan terbentuknya kekalahan makroekonomi serta mempengaruhi pada totalitas perekonomian tercantum sektor perbankan.

Ketidakstabilan kondisi ekonomi akan menyebabkan terdepresiasinya mata uang domestic yang secara signifikan menyebabkan tingginya tingkat bunga dan inflasi yang dapat berdampak pada tingkat pendapatan bank. jika pendapatan bank mengalami kenaikan maka akan berdampak dapa laba bank, laba bank yang mengalami kenaikan maka tingkat kebangkrutan bank akan semakin kecil.

Tetapi hasil dari Penelitian ini menyatakan bahwa inflasi tidak dapat menjadi faktor penentu kebangkrutan bank. Naik turunnya inflasi tidak berpengaruh terhadap laba atau modal bank.

Hasil dari uji regresi legostik menunjukan inflasi tidak dapat menjadi penentu kebangkrutan bank karena nilai signifikansi inflasi sebesar 0,546 lebih besar daripada tingkat alpha yaitu 0,05. Maka dapat disimpulakn bahwa inflasi tidak dapat menjadi penentu kebangkrutan bank, dan $\mathrm{H} 1$ ditolak.

Hasil ini sesuai dengan Penelitian (Othman, Abdul-Majid and Abdul-Rahman, 2018) yang menyatakan inflasi tidak dapat digunakan untuk memprediiksi kebangkrutan bank, sedangkan hasil ini berbeda dengan Penelitian yang dilakukan oleh (Lin and Yang, 2016) dan (Chiaramonte et al., 2016) yang menyatakan bahwa inflasi dapat digunakan untuk memprediksi kebangkrutan bank.

\section{Gross Domestic Product (GDP) Dapat Menjadi Penentu Kebangkrutan Bank $G D P$} merupakan penanda perkembangan ekonomi yang ialah dimensi bernilai dalam memaparkan kapasitas ekonomi sesuatu Negeri. GDP ialah nialai pasar dari semua benda serta pelayanan yang dibuat oleh sesuatu Negeri. Tinggi rendahnya nilai GDP mencerminkan kondisi ekonomi suatu Negara.

Meningkatnya GDP suatu Negara mengindikasikan makroekonomi cenderung baik atau stabil. Semakin tinggi GDP menunjukan kondisi ekonomi suatu Negara dalam keadaan positif. Jika perekonomian suatu Negara dalam keadaan positif berarti usaha-usaha dalam Negara mengalami peningkatan penjualan dan pendapatan.

Jika GDP mengalami penurunan maka dapat dikatakan bahwa sektor-sektor usaha mengalami penurunan penjualan dan pendapatan. Hal ini dapat mempengaruhi perbankan karena jika pendapatan perusahaan mengalami penurunan maka akan memperngaruhi perusahaan dalam membayar pinjaman dan berdampak pada pendapatan bank.

Tetapi hasil dari Penelitian ini menunjukan bahwa GDP tidak dapat menjadi faktor penentu kebangkrutan bank. Naik atau turunnya $G D P$ tidak akan mempengaruhi laba dan modal bank.

Hasil dari uji regresi legostik menunjukan GDP tidak dapat menjadi penentu kebangkrutan bank karena nilai signifikansi inflasi sebesar 0,273 lebih besar daripada tingkat alpha yaitu 0,05. Maka dapat disimpulakn bahwa GDP tidak dapat menjadi penentu kebangkrutan bank, dan $\mathrm{H} 2$ ditolak.

Hasil ini sesuai dengan Penelitian (Othman, Abdul-Majid, and Abdul-Rahman 2018) yang menyatakan GDP tidak dapat menjadi faktor penentu kebangkrutan bank, sedangkan berlawanan dengan penelitian (Lin and Yang 2016) yang menyatakan GDP dapat menjadi faktor.

\section{Equity To To Asset (ETA) Dapat Menjadi Penentu Kebangkrutan Bank}

ETA merupakan penanda keuangan yang dikenakan untuk mengukur semangat maupun kontribusi owner atas kesinambungan upaya dari bank yang berhubungan. Perbandingan ini merupakan perbandingan antara modal sendir dengan seluruhnya asset. Semakin besar perbandingan modal sendiri hingga peranan atau keterikatan pemiliki atas kelangsungan usaha banknya akan semakin tinggi, sehingga campur tangan pemilik dalam mempengaruhi manajemen, meningkatkan kinerja, dan meningkatkan efisiensi banknya secara profesional

Hal ini juga menunjukan dengan adanya modal yang tinggi maka dapat menjaga tinggkat likuiditas, sehingga dapat menurunkan tingkat kebangkrutan bank. Bank dapat mengembangkan usahanya dengan salah 
satu cara yaitu menambahkan asset bank. Asset bank yang dibiayai atau didanai menggunakan modal sendiri dapat membuktikan jika bank mempunyai jenjang kontrol yang kokoh atas usahanya serta tidak dibawah dampak pihak lain.

Jika bank dapat menandai asset menggunakan modal sendiri maka biaya modal yang dikeluarkan akan semakin kecil. Hal ini dapat mempengaruhi tingkat pendapatan bank. Jika tingkat pendapatan bank mengalami kenaikan maka laba bank juga akan mengalami kenaikan dan kemungkinan terjadinya kebangkrutan akan semakin kecil. Semakin tinggi rasio ETA maka kemungkinan terjadinya kebnagkrutan akan semakin kecil, karena dengan equity yang besar dapat menunjukan semakin kecil hutang.

Hasil dari uji regresi legostik menunjukan ETA dapat menjadi penentu kebangkrutan bank karena nilai signifikansi inflasi sebesar 0,047 lebih besar daripada tingkat alpha yaitu 0,05. Maka dapat disimpulakn bahwa ETA dapat menjadi penentu kebangkrutan bank, dan $\mathrm{H} 3$ diterima.

Hasil ini sesuai dengan penelitian (Hsu and Liu 2019) yang menyatakan bahwa ETA dapat menjadi faktor penentu keangkrutan bank, sedangkan hasil ini berlawanan dengan penelitian (Momparler, Carmona, and Climent 2016)yang menyatakan bahwa ETA tidak dapat digunakan untuk menjadi faktor penentu kebangkrutan bank.

\section{Size Dapat Menjadi Penentu Kebangkrutan Bank}

Aset bank dapat menunjukan besar kecilnya size suatu bank. Besar kecilnya suatu ukuran bank dapat mempengaruhi minat investor atau nasabah. Semakin besar ukuran bank, maka akan meningkatkan tingkat kepercayaan investor atau nasabar untuk melakukan investasi atau pembiayaan kepada bank.

Ukuran bank yang besar, mempunyai pangsa pasar yang besar pula, pangsa pasar yang besar dapat meningkatkan pendapatan bank. Penelitian (Kurnia and Mawardi 2012) menyatakan besarnya mempunyai pengaruh positif signifikan terhadap ROA. Artinya semakin besar standar perusahaan, maka prusahaan semakin besar dalam menghasilkan laba. Semakin tinggi laba, maka kemungkinan terjadi kebangkrutan akan semakin kecil.
Hasil dari uji regresi legostik menunjukan Size dapat menjadi penentu kebangkrutan bank karena nilai signifikansi inflasi sebesar 0,000 lebih besar daripada tingkat alpha yaitu 0,05. Maka dapat disimpulakn bahwa Size dapat menjadi penentu kebangkrutan bank, dan H4 diterima. Hal tersebut senada dengan hasil Penelitian (Purnamandari and Badera 2015) yang menyatakan bahwa Size dapat memprediksi kebangkrutan bank.

\section{KESIMPULAN}

Penelitian ini mempunyai tujuan guna mengetahui fakor-faktor penentu kebangkrutan bank pasca krisis ekonomi global di ASEAN. Variabel yang digunakan dalam penelitian ini yaitu, Inflasi, Gross Domestic Product (GDP), equity to total asset (ETA), dan SIZE. Penelitian ini menggunakan beberapa bank ASEAN pada periode 2008-2015. Total sampel yang digunakan sebanyak 1300 bank ASEAN yang didapat dari Bankscope Database. Berdasarkan hasil analisa deskriptif dan logistik dilaksanakan maka kesimpulan yang dapat diambil yaitu:

Hasil Penelitian menunjukan inflasi dan GDP tidak dapat digunakan untuk memprediksi kebangkrutan bank, $\mathrm{H} 1$ dan $\mathrm{H} 2$ ditolak, sedangkan variabel ETA dan Size dapat digunakan unutk memprediksi ebangkrutan bank, $\mathrm{H} 3$ dan $\mathrm{H} 4$ diterima.

Berdasarkan hasil dari Penelitian ini, peneliti menyampaikan rekomendasi untuk penelitian berikutnya dan pihak bank. (1) Menggunakan banyak sumber untuk mendapatkan data bank yang lengkap dan tidak hanya menggunakan bank di ASEAN (2) Menambahkan variabel-variabel yang berkaitan dengan kebangkrutan bank, dan menggunakan model analisa yang lain (3) Hasil penelitain ini menunjukan bahwa besar kecilnya ETA dan SIZE dapat menjadi peringatan dini atau Early Warning System (EWS ) bagi pihak bank dalam langkah untuk mencegah terjadinya kebangkrutan atau kesulitan keuangan.

\section{DAFTAR PUSTAKA}

Firdaus, Rizal Nur. 2016. "Pengaruh Faktor Internal Dan Eksternal Yang Mempempengaruhi Pembiayaan 
Bermasalah Pada Bank Umum Syariah Di Indonesia." El Dinar 3(1):82-108.

Hadyu Hasanatina, Foza, Wisnu Mawardi, and Jurusan Manajemen. 2016. "Analisis Risiko Kebangkrutan Bank Syariah Dengan Metode Zscore (Studi Kasus Pada Bank Umum Syariah Di Indonesia Periode 2008-2014)." Diponegoro Journal of Management $5(2): 1-10$.

Hsu, Chen-Min, and Wan-Chun Liu. 2019. "Bank Failure Model for Asian Financial Crisis and Subprime Mortgage Crisis: A Comparison." Korea and the World Economy 20(1):65-104.

Kasus, Studi, Bank Bca, Tim Pengawas, and Bank Indonesia. 2014. "Indikator Kesulitan Finansil Terhadap Harga Saham Bank :" (January 2004):1-26.

Khadapi, Muamar. 2017. "Pengaruh Car, Roa, Bopo Dan Fdr Terhadap Financial Distress Bank Umum Syariah Di Indonesia Periode 2014-2016."

Kurnia, Indra, and Wisnu Mawardi. 2012. "Analisis Pengaruh BOPO, EAR, LAR Dan Firm Size Terhadap Kinerja Keuangan.” Journal Of Management 1(2):49-57.

Kusmayadi, Dedi. 2012. "Determinasi Audit Internal Dalam Mewujudkan Good Corporate Governance Serta Implikasinya Pada Kinerja Bank." Jurnal Keuangan Dan Perbankan 16(1):147-56.

Lin, Ching Chung, and Shou Lin Yang. 2016. "Bank Fundamentals, Economic Conditions, and Bank Failures in East Asian Countries." Economic Modelling 52:960-66.

MN, Nuryasman, and Verencia Permatasari. 2017. "Dampak Variabel Makroekonomi Dan Indeks Saham Global Terhadap Indeks Harga Lq45 Di Bursa Efek Indonesia." Jurnal Ekonomi 21(3):309-24.

Momparler, Alexandre, Pedro Carmona, and Francisco Climent. 2016. "La Predicción Del Fracaso Bancario Con
La Metodología 'Boosting Classification Tree."' Revista Espanola de Financiacion y Contabilidad 45(1):63-91.

Murni, Asfia, Ekonomika MakroEdisi Revisi,Bandung : Reflika Aditama, 2016.

Othman, Norfaizah, Mariani Abdul-Majid, and Aisyah Abdul-Rahman. 2018. "Determinants of Banking Crises in ASEAN Countries." Journal of International Commerce, Economics and Policy 9(3).

Purnamandari, Ni, and I. Badera. 2015. "Kemampuan Prediksi Rasio Keuangan Dan Ukuran Bank Pada Risiko Gagal Bank.” E-Jurnal Akuntansi 12(2):172-87.

Sudarsono, Heri. 2009. "Dampak Krisis Keuangan Global Terhadap Perbankan Di Indonesia: Perbandingan Antara Bank Konvensional Dan Bank Syariah.” La_Riba 3(1):12-23. 